\title{
微生物による海水中の溶存含窒素化合物 の微量定量法一II.
} 海洋性硝酸還元細菌による硝酸の定量法

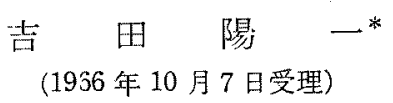

\author{
Microdeterminations of Nitrogenous Compounds in Sea Water, Using \\ Marine Bacteria-II. \\ Determination of Nitrate, Using a Marine Nitrate \\ Reducing Bacterium
}

\section{Yoichi YosHIDA*}

\begin{abstract}
A study was carried out on the microquantitative determination of nitrates present in sea water, the marine nitrate reducer AH 1 being used.

1. Five mililiters of the sample in which the particulate matters such as bacteria have been eliminated by means of centrifugation, $0.5 \mathrm{ml}$ of cell suspension (O.D. $=1.0)$ of the bacterium $\mathrm{AH} 1$ and $0.2 \mathrm{ml}$ of $1 \% \mathrm{Na}$-acetate solution are mixed in the plastic centrifuge tube. The mixture is incubated for $90 \mathrm{~min}$. at $30^{\circ} \mathrm{C}$, the cells in it is eliminated by means of centrifugation, and the nitrite concentration of the supernatant fluid is measured according to the ordinary method.
\end{abstract}

2. Nitrates present in sea water can be determined by this method, even in low concentrations such as $0.1 \sim 10 \mathrm{~N} \mu \mathrm{g}$ at. $/ l$.

海水中に打るる硝酸（坮）の定量法には，従来，海水中に多量に存在する塩類に阻害されない万法として，

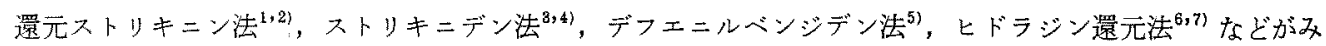

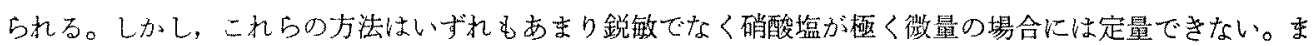
た，反応液の温度，水素イオン濃度，去の他の諸条件により影響をうけやすいなど多くの欠点がある。

したがつて，本報ては海洋性硝酸還元細菌を用いて海水中の硝酸を還元させ，生成した正硝酸を湘定して， 海水中に極めて微量に存在する硝酸を定量する方法を試みた。

なお、この上らに硝酸還元細菌を用いて硝酸を定量する方法は，最初，GARNER ら

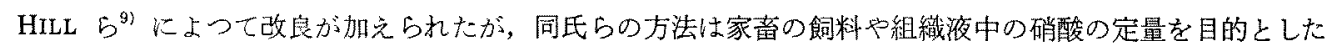
ものであり，また反応液中には growing cell の状態で培善液そのままが加劣られているため，測定範囲が かなり高謴度 $\left(2 \sim 200 \mathrm{KNO}_{3} \mathrm{mg} / l\right)$ にある。このため，同氏らの方法ではきわめて微量に存在している海 水や淡水中の硝酸の定埋には適さない。

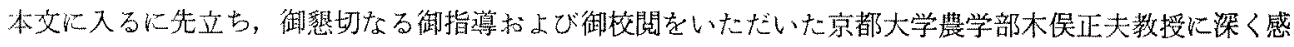
䀯する。

\footnotetext{
*京都大学压学部水産学教室 (Dept. Fish, Fac. Agr., Kyoto Univ., Maizuru, Japan)
} 


\section{実 験 方 法}

供試菌海洋性硝酸還元細菌 AH1*を用いた。この紐菌注数十種の淡水性および海洋性細菌から選九 だもので，硝酸を亜硝酸に還元するが，亜硝酸を還元せず，むたその cell suspensionは比较的少量の水素 供与体（酶酸ナトリウム）を加えるだけで，海水中のきわめて微量の硝酸を弫とんど $100 \%$ 亚硝酸に還元 する。

なお，細菌の保存培養は，寒天斜面培養基に接種して $25^{\circ} \mathrm{C}$ で培養を行ない，2 週間每に新しい培養基に 植えかえて保存する。この場合の培養基はZ ZOBELLの $2216^{10)}$ と同様のもの(硝酸塩を添加)を用いる。

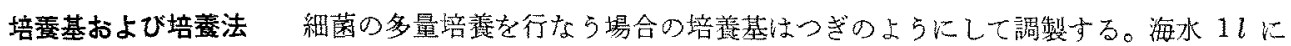
対しペプトン $5 \mathrm{~g}$, 硫酸第 1 鉄 $0.05 \mathrm{~g}$, 第 1 燐酸カリウム $0.05 \mathrm{~g}$, 硝酸カリウム $0.3 \mathrm{~g}$ を加え，さらにフェ ノールレッドの微量と $50 \%$ 炭酸カリウム溶液数滴を加克て溶液の色を橙色とする。この溶液を $15 \times 150 \mathrm{~mm}$ の詿験管に $6 \mathrm{~m} l$ ，お上び $1 l$ 容の三角フラスコに $800 \mathrm{ml}$ を入れ，15 ポソドで 15 分間高王隇菌をする。 また細菌の培養はつぎのよ5にして行な5。すなわち, 試験管に調製した培妻基に, 前記保存培養の一部を 白金線で接種し， $30^{\circ} \mathrm{C} て ゙ 24$ 時間静置培荃を行なつた後, この培着液の $3 \mathrm{ml}$ を $1 l$ 容の三角フラスコに調

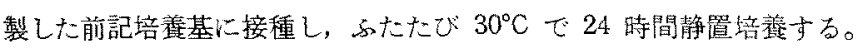

Cell suspension の調製前記の培㝨液を $8,000 \mathrm{~g}, 30$ 分間の邈心分離 (富永製遠心器, 口ーター No. 9 使用）により集菌し，得ら九た菌体を $50 \mathrm{ml}$ の硝酸塩を含まない海水中に suspend し，ふたたび 8,000 $\mathrm{g}, 10$ 分間の遠心分離を行なつて集菌寸る。この操作を2 3 回くり返して菌体の洗浄を行ない，洗浄液中 に亜硝酸の存在が認められなくなつた後，ふたたび菌体を適量の，硝酸塩を含まない海水中に suspend し， 吸光度 O.D. 1.0 に調整する(ライッ光電比色計，Aフィルタ一使用)。この cell suspension はその 主ま定量と用いるか，または $-20^{\circ} \mathrm{C}$ 前後で湅結して保存し，使用直前に解凍したものを用いる(倲結期間 は2 週間以内とする)。

器具の洗浄使用器具はちべて器壁に微量の硝酸が残存付着しない上らに十分注意深く洗浄しなければ ならないが，特に反庍に用いるプラスチック制のセントりチューブは蒸溜水をチューブ内一ぱいに満たして 一昼夜故置し，後蒸溜水を搭て，水を十分切り，上く乾燥したものを用いる。

測定操作 严試水中の細菌その他の particulate matter を除くために, 試水を低温 $\left(+2^{\circ} \mathrm{C}\right.$ 前後 $)$ のもとで， $8,000 \mathrm{~g}, 10$ 分間の遠心分離を行ない，その上澄液をとる。つぎに，この上澄液の $5.0 \mathrm{ml}$ をプ ラスチック製のセントリチューブ $(15 \times 100 \mathrm{~mm})$ に入れ，これに $1 \%$ の酢酸ナトリウム溶液 $0.2 \mathrm{ml}$ と，

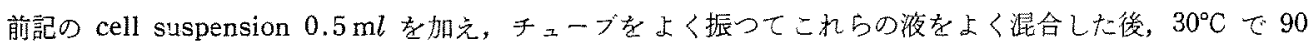
分間反俯させる。反応後, チューブをとり出し， $10,000 \mathrm{~g} て ゙ 5$ 分間の薏心分離 (富永慜ローターNo. 2 使用)

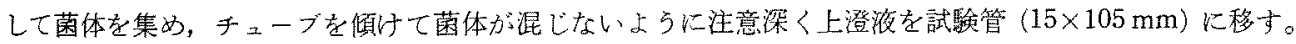
これにグリース・ロミン試薬を $0.05 \mathrm{~g}$ 加えて発色させ, 30 分間放置した後, $1 \mathrm{~cm}$ の cuvette を用いて,

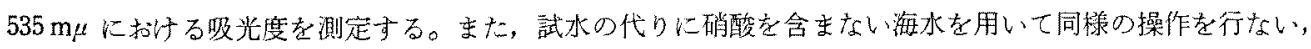
得られた値を control とする。この值を先に得られた值から差引き，別に作製した桧量曲線を用いて硝酸 量を求める。

なお，試水中に最初から亜硝酸が含まれている場合には，常法にしたがつてこの亜硝酸量を求め，この値 を先炕得られた値から差引いて真の硝酸量とする。

\section{実 験 結 果}

西硝酸生成量の経時的変化 （海水中に硝酸カリウムを $5 \mu \mathrm{M}(5 \mathrm{~N} \mu \mathrm{g}$ at. $/ l)$ 抢上び $10 \mu \mathrm{M}$ 添加したも のを試水として用い，反応時間の経過心伴ら亜硝酸生成量の变化をしらへた。得られた結果はFig. 1 に示

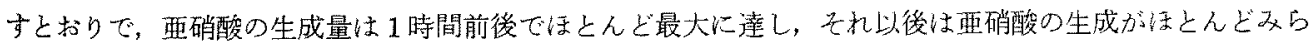

\footnotetext{
*同定中である。
} 


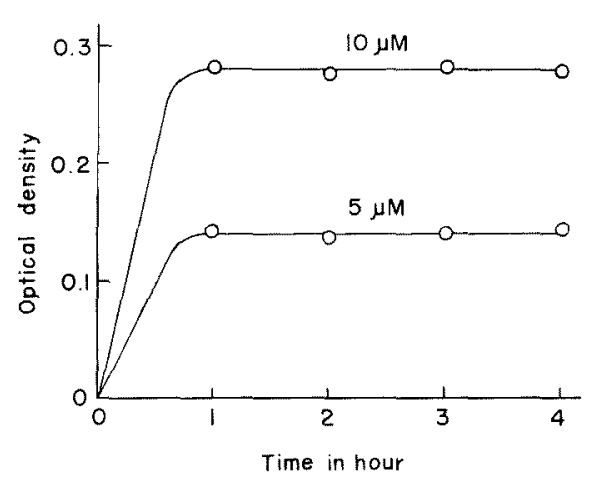

Fig. 1. Reduction of nitrate to nitrite by the marine nitrate reducing bacterium $\mathrm{AH} 1$.

れなくなる。硝酸カリウムの代りに，西硝酸力リウム を $10 \mu \mathrm{M}$ 加元た試水について同様の操作を行ない,

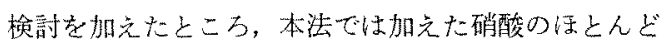
$100 \%$ が約 1 時間で覀硝酸に還元されることがわかつ た。

検量曲線の作成と測定範囲について 海水中に硝

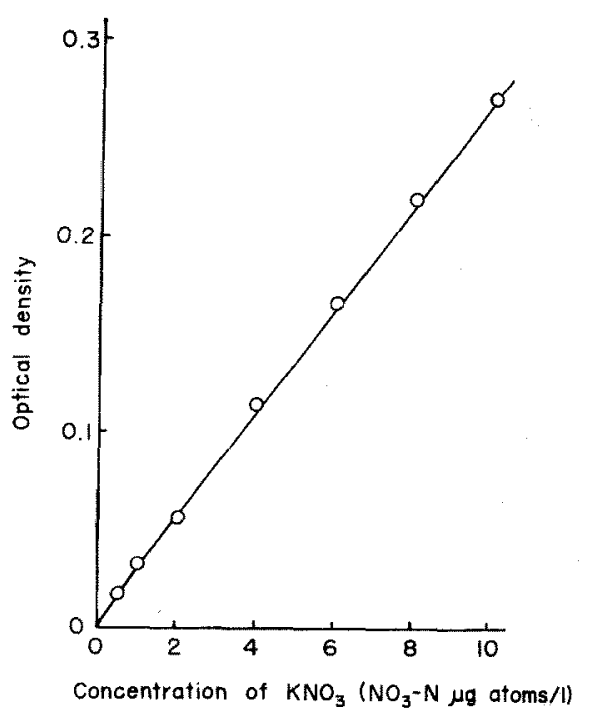

Fig. 2. Standard curve of ammonia determined by the present method using the marine nitrate reducing bacterium AHI. Karium nitrate was dissolved in nitrate free sea water.

酸カリウムを種々の濃度に添加して硝酸カリウムの標準液列を調製し，これらについて測定した結果，添加 した硝酸量と吸光度（生成した亜硝酸量）との関俰は Fig. 2 に示すとおりで，雨者の間にははとんど直線

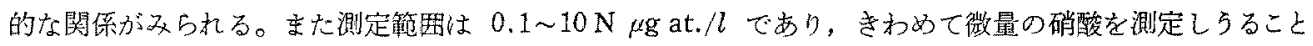
がわか子。

\section{考察}

この方法によれば上述のように海水中に存在するきわめて徽量の硝酸を定量することができる。したがつ て, 徒来非常に困難とされていた，200 m 以浅の，硝酸含量のきわ好少ない海水中の硝酸の定量法として この方法は非常に好適であると思われる。なお現在菌体の長期保存法について研究中である。

要 約

海洋性硝酸還元細菌 AH1 を用いて，海水中に微量に存在する硝酸（塩）を $0.1 \mathrm{~N} \mu \mathrm{g}$ at. $/ l$ まて測定し得 る新しい硝酸の微量定星法を考案した。

\section{文献}

1) 日本海洋学会編：海洋微測指針，167(1955).

2) R. FukaI: Jour. Oceanog. Soc. Jap., 11, $19 \sim 23$ (1955).

3) B. M. G. ZWICKER and R. J. Robinson: J. Mar. Res., 5, 214 232 (1944).

4) E. MARVIN: ibid., 14, $79 \sim 87$ (1955).

5) W. R. G. A thins: Jour. Conseil, 20, 153 155 (1954).

6) J. B. Mullin and J. P. Riley: Anal. Chim. Acta, 12, 464 480. (1955).

7) J. D. H. Strickland and T.R. Parsons: Bull. Fish. Res. Bd. Canada, 125, $61 \sim 69$ (1960).

8) G. B. Garner, J.S. Baumstark, M. E. Muhrer, and W. H. Pfander: Anal. Chem., 28, 1589 $\sim 1591$ (1956).

9) R. M. Hill, H. Pivnick, W. E. EngelhaRd, and M. Bogard: Agricult. Food Chem., 7, 261 $\sim 264$ (1959).

10) C. E. ZoBell: "Marine Microbiology", p. 41, Chromica Botanica Company, Waltham (1946). 